\title{
Water-Energy-Food Nexus in Large Asian River Basins
}

\author{
Marko Keskinen * and Olli Varis \\ Water \& Development Research Group, Aalto University, P.O. Box 15200, Aalto 00076, Finland; olli.varis@aalto.fi \\ * Correspondence: marko.keskinen@aalto.fi; Tel.: +358-50-563-8030
}

Academic Editor: Arjen Y. Hoekstra

Received: 13 July 2016; Accepted: 29 August 2016; Published: 12 October 2016

\begin{abstract}
The water-energy-food nexus ("nexus") is promoted as an approach to look at the linkages between water, energy and food. The articles of Water's Special Issue "Water-Energy-Food Nexus in Large Asian River Basins" look at the applicability of the nexus approach in different regions and rivers basins in Asia. The articles provide practical examples of the various roles and importance of water-energy-food linkages, but also discuss the theoretical aspects related to the nexus. While it is evident that any application of the nexus must be case-specific, some general lessons can be learnt as well. Firstly, there are a variety of interpretations for the nexus. These include three complementary perspectives that see nexus as an analytical approach, governance framework and emerging discourse. Secondly, nexus is-despite its name-a predominantly water-sector driven and water-centered concept. While this brings some benefits by, e.g., setting systemic boundaries, it is also the nexus' biggest challenge: If the nexus is not able to ensure buy-in from food and energy sector actors, its added value will stay limited. Ultimately, however, what really matters is not the approach itself but the processes it helps to establish and outcomes it helps to create. Through its focus on water-energy-food linkages—rather than on those themes separately-the nexus is well positioned to help us to take a more systemic view on water, energy and food and, hence, to advance sustainable development.
\end{abstract}

Keywords: water-energy-food nexus; transboundary water-energy-food nexus; river basin; transboundary river; water security; energy security; food security; Central Asia; South Asia; Southeast Asia; Mekong

\section{Introduction: The Emergence of Water-Energy-Food Nexus}

Water-energy-food (security) nexus aims to "enhance water, energy and food security by increasing efficiency, reducing trade-offs, building synergies and improving governance across sectors" [1] (p. 4). That was the description in the Background Document for Bonn2011 Conference on The Water, Energy and Food Security Nexus, held in November 2011 [1]. Since then, the number of nexus-related activities, projects and publications have boomed, with a variety of actors using nexus concept to guide, frame and reflect upon their activities. For example, international Future Earth research platform included the management of water-energy-food synergies and trade-offs as one of the eight global sustainability challenges [2], the Food and Agriculture Organization of the United Nations (FAO) has looked at the applicability of the nexus in different contexts [3,4], and the European Commission added food-energy-water-climate linkages among the topics for its Horizon 2020 research and innovation program [5].

The rapid emergence of the nexus can be seen as rather surprising, given that the nexus as a concept is still not clearly defined and-despite efforts, in particular by Germany [6,7]—it was included neither in the Outcome Document of Rio+20 nor in the Sustainable Development Goals. 
The nexus as an approach thus lacks an officially recognized status that for example Integrated Water Resources Management (IWRM) has received.

There must therefore be something else that has attracted attention to the nexus. We argue that the emergence of the nexus is related to three interlinked drivers: crucial importance that water, energy and food have for humanity and related need to ensure their security; enhanced awareness of the societal and economic risks included in the mounting resource scarcities; and the failure of existing water-related management approaches-most notably IWRM — to engage other sectors to address water-related challenges.

The rationale behind the first driver is clear: water, energy and food are the key prerequisites for the existence of humankind. The three are also closely linked, with water acting as an enabler for both food and energy production and being at the same time a major target for adverse environmental effects of activities in those sectors [8,9]. While all this is well known, the wide-ranging societal and economic impacts of increasing water and resource scarcity (e.g., $[10,11])$ have been properly recognized only during the past years, and can thus be considered as the second driver for the nexus [1]. This is exemplified by the World Economic Forum's Global Risks Report 2015 [12], which for the first time placed "water crises" as the most important global risk in terms of impact—ahead of infectious diseases, weapons of mass destruction, interstate conflicts, and even failure of climate change adaptation (in 2016 water crisis ranked third, after climate change and weapons of mass destruction [13]). The World Economic Forum has also broadened its view on water-related risks, changing the term "water supply crisis" to "water crisis", and revising the risk category of water crisis from environmental to societal risk [13]. The increased awareness about resources scarcities has also translated into heightened attention to security-related aspects of water, energy and food: Instead of just using and managing the different resources and related sectors, the attention is increasingly also on securing both availability and access to them.

The third driver is linked to the planning and management processes of water and related resources. In terms of water, IWRM is arguably the most commonly accepted global framework due to its recognition in several UN conferences and agreements-most recently within the context of Sustainable Development Goals [14]. While IWRM has been successful in promoting integrated management of water resources, it has not always been that successful in engaging water-related sectors-most importantly food and energy-into its implementation. Despite the critical role that those sectors have on water use and degradation of aquatic ecosystems, IWRM has remained water sector orientated and often rather technical management process. We see two main reasons for this: first of all IWRM is by its definition all-encompassing, linking water to all relevant policy sectors. Secondly, the IWRM processes have not been very strong in pushing the debate "out of the water box", but other sectors are instead often considered as kind of externalities that are to be managed under IWRM framework [15]. The nexus changes this by its very name, recognizing that it is first and foremost about water, energy and food (referring to entire sectors, not just their water-using parts) and focusing on their specific linkages, synergies and trade-offs.

\section{Link to Practice: Nexus in Large Asian River Basins}

Any discussion about the characteristics of a nexus approach remain theoretical unless linked to actual planning and decision-making processes on the ground. That was also the aim of our Special Issue: to see what kind of practical benefits and challenges the emerging nexus approach could accrue when actually examined, analyzed and applied in differing management contexts.

The geographical focus of our Special Issue is very wide, covering Asia and its large river basins. Majority of these basins are transboundary, i.e., shared by more than one nation state. While recognizing that the nexus approach should not be applied only within water-bound boundaries, i.e., catchments, we decided to set the focus on large Asian river basins as they present particularly challenging management settings due to their scale and variety of actors. In addition, there is already a rich literature on their water, energy and food-related characteristics and management processes: 
This makes it easier to compare the nexus with other management approaches and thus to discuss its potential value added. Finally, despite all these activities, the situation in many transboundary basins remains contentious and even 'deadlocked', with different sectoral actors and nation states failing to agree on the most suitable ways forward. The geographical focus also corresponded with the Academy of Finland-funded NexusAsia project (http://www.wdrg.fi/nexusasia), which built on our Water and Development Research Group's earlier research related to the water resources management in large Asian river basins (e.g., [16-20]).

Of particular focus in this Special Issue were three regions and their related rivers: Central Asia, South Asia and the Mekong Region. Over 3.3 billion people live in these three regions, i.e., well over $40 \%$ of the world's population, with over 1.1 billion living within the seven main transboundary river basins of Amu Darya, Syr Darya, Ganges-Brahmaputra-Meghna, Indus, Irrawaddy, Salween and Mekong [9]. The regions are, however, very different, with South Asia clearly the most highly populated [20]. Also the river basins have differing characteristics in terms of their hydrology, connection to food and energy production, and future plans for development. At the same time, all regions have plans for the development of water infrastructure, including large hydropower dams, with direct implications to water, energy and food security.

\section{Contributions from the Articles}

Water's Special Issue, "Water-Energy-Food Nexus in Large Asian River Basins" (http:/ /www. mdpi.com/journal/water/special_issues/Water-Energy-Food), include 11 articles from altogether 35 different authors. Geographically, a majority of the articles look at Central Asia [21-25] and the Mekong [26-29], with one of the articles looking at Central Asia, South Asia and the Mekong [9] and two others including case study areas outside these three regions [25,30]. Methodologically, the articles address both theoretical and practical aspects related to the nexus. While all articles include elements from both of these, six of them can be seen to be more practical, i.e., context-driven [21-24,26,28], while five articles focus more on the theoretical discussion about the nexus as an approach $[9,25,27,29,30]$. Next, we will provide a concise summary for all the articles, organized according to their geographical (Central Asia and Mekong) and methodological (theory) focus.

In their article on Central Asia's Syr Darya River Basin, Soliev et al. [21] emphasise the importance of historical perspective and more rigorous institutional analysis on water-energy-food nexus and benefit sharing in transboundary river basins. Through their insightful analysis of water-related development from 1917 until present day in the Ferghana Valley, the authors recognize five different periods for the cooperation between Kyrgyzstan and Uzbekistan. Each of these periods has differing benefit sharing mechanisms and related types of benefits. The analysis powerfully shows the evolution and implications of changing institutional settings for shaping water-related management decisions as well as transboundary cooperation.

The article by Guillaume et al. [22] provides two significant views to this Special Issue. First, it gives an in-depth historical assessment of the trajectories of water scarcity and consumption in Central Asia, applying global water data to selected Food Production Units in Uzbekistan, Kazakhstan, Kyrgyzstan, Tajikistan, Turkmenistan, and Afghanistan. Second, the authors use concepts stemming from resilience and socio-ecological system theory to identify five transferable principles that are seen to be particularly relevant for managing transboundary water-energy-food nexus. These principles are: (1) the subsystems included/excluded from the nexus are case-specific and should be consciously scrutinized; (2) consensus is needed on what boundaries can acceptably be crossed within the nexus; (3) there is a need to understand how reducing trade-offs will modify system dependencies; (4) global stakeholders have both a responsibility and right to contribute to the shaping of the nexus; (5) combining data with global and local perspectives can help to enhance transferability and understanding of shared problems in our globalized world [22].

The analysis by Wegerich et al. [23] looks at water security in Syr Darya River Basin through case studies focusing on the water management of irrigated agriculture. Noting that current definitions 
for water security largely forget the supply-side of water security, the authors move on to analyze in a novel manner past and current water security approaches in Syr Darya Basin. The results indicate that the majority of water-related international activities in the basin have been either at very local level or at international level, with the importance of the meso-level and its actors (including public irrigation departments) going largely unnoticed. In conclusion, the authors call for the long-term strengthening of public administration—so-called water bureaucracy—as it is often the weakest link for water security.

Jalilov et al. [24] provide an experimental case study focusing on Amu Darya River Basin and its water-energy-agriculture nexus. Using a hydro-economic model, the authors estimate the energy- and agriculture-related economic benefits from a major water infrastructure development project, namely the Rogun hydropower plant. The results show that differing operating schemes for the plant would increase the total energy-agriculture benefits while ensuring environmental flow needed to maintain key water-related ecosystems. This emphasizes the potential for benefit sharing between the basin countries, and also indicates that nexus synergies are indeed achievable: It seems possible to build and operate a dam in a way that would simultaneously enhance energy- and food-related benefits from the current state. The authors also note that any practical application of water-energy-food nexus must be context-specific and, if necessary, also include other relevant sectors. In the case of Amu Darya, the analysis must also consider economically very important—and water-intensive—non-food agriculture such as cotton.

Moving to the Mekong Region, Keskinen et al. [26] discuss the water-energy-food nexus in the context of the Tonle Sap Lake in Cambodia. The analysis shows that that the current plans for large-scale hydropower in the Mekong will radically alter water and food security at both local and national level, and the nexus is thus a very timely, complementary concept to address the development challenges in the region. As result, for example the Mekong River Commission MRC - that has for years built its activities on IWRM concept-concluded in its most recent Basin Development Plan that addressing water-related trade-offs "requires strong IWRM understanding and water-food-energy nexus thinking" [31] (p. 42). Keskinen et al. also discuss the benefits of the nexus as an approach, noting that within their research project the nexus was particularly useful in facilitating collaboration and stakeholder engagement. The authors conclude that when compared to IWRM, the nexus is simultaneously more focused (spelling explicitly out the sectors that are to be included) and broader (expanding the discussion from mere water resources management to a general discussion about water, energy and food security). At the same time, however, there is a danger that the themes and aspects that are not explicitly included-such as livelihoods, climate change, or the environment-are simply left out or get secondary weight.

Matthews and Motta [28] provide a detailed analysis of the actual drivers for the Mekong's hydropower boom, focusing on the critical role that Chinese state-owned enterprises have for hydropower investments. Using a political economy analysis, the authors clearly show the powerful political and economic forces behind hydropower development. Importantly, the analysis also indicates how such forces create narratives that downplay the water-energy-food nexus interconnections and position hydropower as a win-win for both upstream and downstream states-in contrast to scientific studies that demonstrate the substantial trade-offs related to hydropower development. This finding emphasizes the political dimension of the nexus, and reminds us that the way the nexus is defined and used often differ greatly depending on the actors and their ultimate interests.

The Special Issue also includes five articles that have more theoretical view on the nexus. Belinskij [27] provides a refreshingly different view on the entire approach, looking at how the international water law supports the nexus approach in the context of international river basins. Focusing on two international conventions (UN Watercourses Convention and ECE Water Convention) and using the Mekong as a case study, the analysis shows that international water law provides a useful platform for the cooperation between states and different sectors. While international water law supports the transboundary nexus approach by offering an institutional framework, it does not 
offer concrete specifications for its procedural elements: agreeing on this remains the responsibility of riparian states. The author concludes that the most difficult part of the nexus cooperation in transboundary river basins is the reconciliation of different water uses in situations where there is not enough water to meet all the competing needs. In such situations, the general provisions in international water law on equitable and reasonable utilization and on the minimization of harmful transboundary effects become central.

Endo et al. [30] provide an insightful methodological view for the nexus, drawing on a comparative analysis of an array of different methods to look at the water-energy-food linkages. Covering both qualitative methods (questionnaire surveys, ontology engineering, and integrated maps) and quantitative methods (physical models, benefit-cost analysis, integrated indices, and optimization management models), the authors consider the pros and cons of each method with the help of set of local case studies from Japan and the Philippines. The authors also discuss the different stages and scales within the nexus analysis process that the methods can provide most contribution to, noting the importance of both temporal and spatial scale. The article, thus, reminds us how the nexus as an approach connects to already existing methods, and how the nexus linkages can be examined through a variety of different methods.

De Strasser et al. [25] discuss a methodology to assess the water-energy-food-ecosystem nexus in transboundary river basins. Drawing on groundbreaking work by the Task Force on the Water-Food-Energy-Ecosystems Nexus under the UNECE Water Convention, the authors introduce the Transboundary River Basin Nexus Approach (TRBNA) methodology and present findings from its application in three transboundary river basins: the Alazani/Ganykh, the Sava and the Syr Darya. The TRBNA methodology includes a six-step process, consisting of following steps: (1) Socio-economic and geographical context; (2) Identification of key sectors and key actors; (3) Analysis of key sectors; (4) Intersectoral issues; (5) Nexus dialogue; and (6) Solutions and benefits. Through their in-depth description of the TRBNA methodology, the authors provide a unique view of an actual nexus assessment process implemented within the political context of an intergovernmental organization. Methodologically, the authors conclude that the characteristic that makes the nexus approach innovative is the shift from a sector- or resource-centric perspective to a multi-centric one: nexus takes into account the links and dynamics between resource systems to harmonize their outlook and management. Noting that the nexus is often compared to IWRM, the authors also note that the traditional integrated approaches typically have limited analytical scope and often do not consider re-enforcing stresses or indirect links.

The article by Pittock et al. [29] introduces an influence model that can be used to systematically assess the water, energy and food nexus in large rivers. With the help of a series of influence diagrams, the authors model the hydropower-food supply nexus in the Lower Mekong River Basin. The diagrams show in visually powerful manner that the nexus in the Mekong is part of a complex system where an intervention in one aspect-for example construction of hydropower dam-will have cascading consequences for a wide range of other sectors in the socio-ecological system. In this way, the influence diagrams illustrate vividly the need for strategic management interventions, focusing on the key points of leverage where such interventions have the biggest potential to change the outcomes and to minimize negative impacts. The authors also note that the use of influence models facilitates systematic nexus analysis by identifying links across sectors, enabling discourse among actors on trade-offs and synergies across water, energy, food and other sectors.

The Special Issue is concluded with an article by Keskinen et al. [9], discussing the applicability of water-energy-food nexus in transboundary contexts based on novel comparative analysis as well as on key findings from the other articles of the Special Issue. The authors start by providing a set of definitions for the nexus, recognizing three perspectives that see the nexus as an analytical tool, governance framework and as an emerging discourse. The analysis of three Asian regions-Central Asia, South Asia and the Mekong Region-and their related transboundary river basins builds on comparative nexus triangles that aim to visualize the key nexus linkages in all these regions. Following, 
the authors discuss the implications that the nexus approach has for transboundary context and vice versa.

\section{Key Findings and Conclusions}

Together, the articles constituting the Special Issue produce several important findings. In terms of the geographic focus of this Special Issue, the articles illustrate clearly the crucial linkages that water has with both energy and food production in different regions of Asia. Equally important are the linkages between energy and food security: Irrigated agriculture is a heavy user of energy (hence benefiting from enhanced energy security), while several forms of energy production-particularly hydropower and bioenergy - have direct impacts on food security.

The articles also show how strongly both energy and food production impact the river systems, with large-scale hydropower development being a particularly powerful—and contested-driver in a number of river basins. Such changes also translate into tensions between different water uses, both within and between the countries sharing the same river basin. Indeed, the upstream-downstream tensions over the water use-commonly including both energy (hydropower) and food (agriculture and/or fish) - in transboundary river basins of Asia seem to be rather a rule than an exception. This underlines the political dimension of the nexus (see also [32,33]), but also emphasizes the need to look beyond the river basin and water use per se, towards broader regional linkages and benefits related to water, energy and food. The articles also note that water-energy-food linkages in the study regions evolve over time, and that intensifying water and resource scarcities are likely to reinforce the already grand challenges related to such linkages.

Interesting methodological findings emerge also in relation to the nexus approach itself. First of all, it becomes clear that there are varying interpretations of the nexus, with different authors emphasizing different dimensions and also extending its scope from mere water-energy-food to include for example non-food crops and ecosystems. As noted by Keskinen et al. [9] in this issue, three complementary perspectives can therefore be established for the nexus, viewing it as an analytical approach, governance framework and emerging discourse. They also note that while the need for integration in relation to the nexus generally focuses on the linkages between three nexus sectors, it seems as important to understand the cross-level linkages between these different nexus perspectives and related disciplines [9]. Several articles also discuss the different scales related to the nexus. As concluded by Endo et al. [30] in this issue, the consideration of both vertical and horizontal scales and dimensions is needed to reduce trade-offs and to optimize the water-energy-food linkages.

Although the importance of water-energy-food linkages is clear, actual empirical evidence on the water-energy-food nexus approach remains relatively thin. This is visible also in this Special Issue, with the majority of the articles actually focusing more on the nexus as a theme (water-energy-food) than as an actual approach for analysis and/or planning and policy-making. On the other hand, several articles also discuss the methodological aspects of the nexus, including the article describing the pioneering work done by the UNECE and its partners on a thorough nexus assessment process in different transboundary river basins [25], as well as a useful methodological review by Endo et al. [30].

The articles also portray the nexus as a clearly water-centered concept-partly due to the defined scope (large Asian river basins) of the Special Issue. Such water-centrism has been, however, noted also by other authors, already starting from the Bonn2011 Conference that placed "available water resources" in the center of its triangle diagram depicting the water, energy and food security nexus [1] (p. 16). In this way, it becomes natural to compare nexus with other water management approaches, most importantly IWRM. It also makes it natural to focus the attention to river basin as a political and geographical unit, and water use and allocation as key elements of the nexus.

We should, thus, acknowledge upfront that one of the reasons for the very existence of the nexus is the need to find new ways to cope with increasing water scarcity and deterioration of aquatic ecosystems, and, hence, to address the pressures posed by food and energy production on water ecosystems. Instead of "available water resources" at the center of the Bonn2011 diagram, "aquatic 
ecosystems" feels in many ways more appropriate focus (see also [25,34]). This would emphasize the importance of environmental impacts (and align the nexus better with common paradigms, such as ecosystem approach) and also remove the possible misinterpretation where water is seen merely as a resource to be allocated to and shared between agricultural and energy producers.

We argue that the water and resource-centrism is also the biggest challenge of the nexus. As illustrated by number of articles in this Special Issue, the ultimate success of the nexus depends from its ability to guarantee a buy-in also from the actors of energy and food sectors. We believe that such buy-in is best ensured if those actors feel that the nexus process provides them with something useful and that they are treated as equal partners, not just 'externalities' causing pressures on water.

Ultimately, however, the discussion about the nexus approach is not that relevant. What really matters is not the approach itself but the theoretical and practical processes it helps to establish and outcomes it helps to create (see also [35]). For us the key opportunity provided by the nexus is two-fold: its clear definition of the themes included (setting focus), and its emphasis on the linkages and feedback loops between those themes (not only on the themes per se). If the nexus in this way helps us to climb a step higher-from the sectoral valleys towards the mountain of sustainability-and take a more systemic view on those themes, then it is likely to live up to its expectations.

Acknowledgments: This Special Issue brought together a unique set of experts. Thank you Ilkhom Soliev, Kai Wegerich, Jusipbek Kazbekov, Joseph Guillaume, Matti Kummu, Stephanie Eisner, Daniel Van Rooijen, Nozilakhon Mukhamedova, Shokhrukh-Mirzo Jalilov, Paradis Someth, Aura Salmivaara, Antti Belinskij, Aiko Endo, Kimberly Burnett, Pedcris M. Orencio, Terukazu Kumazawa, Christopher A. Wada, Akira Ishii, Izumi Tsurita, Makoto Taniguch, Nathanial Matthews, Stew Motta, Lucia de Strasser, Annukka Lipponen, Mark Howells, Stephen Stec, Christian Bréthaut, Mirja Kattelus, Miina Porkka, Timo Räsänen, Jamie Pittock, David Dumaresq and Andrea Bassi for sharing your views related to the water-energy-food nexus and large Asian river basins. Special thanks for the editorial team of the Water journal for your collaboration throughout the editorial process. Thank you also for the numerous reviewers, who shared their time, expertise and critical views to improve the articles as well as this Editorial. Finally, thank you to our colleagues at Aalto University's Water \& Development Research Group-particularly Shokhrukh-Mirzo Jalilov and Joseph Guillaume-for your support throughout this process. The work for the Special Issue was enabled by the funding from the Academy of Finland (\#269901 NexusAsia), while the work for this editorial was done under Strategic Research Council (SRC) funded Winland project.

Conflicts of Interest: The authors declare no conflict of interest.

\section{References}

1. Hoff, H. Understanding the Nexus; Background Paper for the Bonn2011 Conference: The Water, Energy and Food Security Nexus; Stockholm Environment Institute: Stockholm, Sweden, 2011.

2. Future Earth. Future Earth 2025 Vision; International Council for Science: Paris, France, 2014.

3. Food and Agriculture Organisation of the United Nations (FAO). An Innovative Accounting Framework for the Food-Energy-Water Nexus-Application of the MuSIASEM Approach to Three Case Studies; FAO: Rome, Italy, 2013.

4. Flammini, A.; Puri, M.; Pluschke, L.; Dubois, O. Walking the Nexus Talk: Assessing the Water-Energy-Food Nexus in the Context of the Sustainable Energy for All Initiative; Food and Agriculture Organisation of the United Nations (FAO): Rome, Italy, 2014.

5. European Commission. Horizon 2020 Topic: Integrated Approaches to Food Security, Low-Carbon Energy, Sustainable Water Management and Climate Change Mitigation. Available online: http:/ /ec.europa.eu/ research/participants/portal/desktop/en/opportunities/h2020/topics/water-2b-2015.html (accessed on 10 August 2016).

6. Policy Recommendations—Bonn Conference 2011: The Water, Energy and Food Security Nexus—Solutions for the Green Economy; Bonn2011 Conference: Bonn, Germany, 2011.

7. Brandi, C.; Richerzhagen, C.; Stepping, K. Post 2015: Why is the Water-Energy-Land Nexus Important for the Future Development Agenda?; German Development Institute (DIE): Bonn, Germany, 2013.

8. Olsson, G. Water, energy and food interactions-Challenges and opportunities. Front. Environ. Sci. Eng. 2013, 7, 787-793. [CrossRef] 
9. Keskinen, M.; Guillaume, J.; Kattelus, M.; Porkka, M.; Räsänen, T.; Varis, O. The Water-Energy-Food Nexus and the Transboundary Context: Insights from Large Asian Rivers. Water 2016, 8, 193. [CrossRef]

10. Kummu, M.; Gerten, D.; Heinke, J.; Konzmann, M.; Varis, O. Climate-driven interannual variability of water scarcity in food production potential: A global analysis. Hydrol. Earth Syst. Sci. 2014, 18, 447-461. [CrossRef]

11. Salmivaara, A.; Porkka, M.; Kummu, M.; Keskinen, M.; Guillaume, J.; Varis, O. Exploring the Modifiable Areal Unit Problem in Spatial Water Assessments: A Case of Water Shortage in Monsoon Asia. Water 2015, 7 , 898-917. [CrossRef]

12. World Economic Forum. Global Risk Report 2015, 10th ed.; World Economic Forum: Geneva, Switzerland, 2015.

13. World Economic Forum. Global Risk Report 2016, 11th ed.; World Economic Forum: Geneva, Switzerland, 2016.

14. United Nations. Transforming Our World: The 2030 Agenda for Sustainable Development. In A/RES/70/1: Resolution Adopted by the General Assembly on 25 September 2015; United Nations General Assembly, 2015. Available online: http://www.un.org/ga/search/view_doc.asp?symbol=A/RES/70/1\&Lang=E (accessed on 3 October 2016).

15. Varis, O.; Enckell, K.; Keskinen, M. Integrated water resources management: Horizontal and vertical explorations and the 'water in all policies' approach. Int. J. Water Resour. Dev. 2014, 30, 433-444. [CrossRef]

16. Keskinen, M. Water resources development and impact assessment in the Mekong Basin: Which way to go? AMBIO 2008, 37, 193-198. [CrossRef]

17. Mehtonen, K.; Keskinen, M.; Varis, O. The Mekong: IWRM and Institutions. In Managemeng of Transboundary Rivers and Lakes; Varis, O., Tortajada, C., Biswas, A.K., Eds.; Springer: Berlin, Germany, 2008.

18. Varis, O.; Rahaman, M.M. The Aral Sea Keeps Drying out but is Central Asia short of water? In Central Asian Waters: Social, Economic, Environmental and Governance Puzzle; Rahaman, M.M., Varis, O., Eds.; Water \& Development Publications-Helsinki University of Technology: Esbo, Finland, 2008; pp. 3-9.

19. Rahaman, M.M.; Varis, O. Integrated water management of the Brahmaputra basin: Perspectives and hope for regional development. Nat. Resour. Forum 2009, 33, 60-75. [CrossRef]

20. Varis, O.; Kummu, M.; Salmivaara, A. Ten major rivers in monsoon Asia-Pacific: An assessment of vulnerability. Appl. Geogr. 2012, 32, 441-454. [CrossRef]

21. Soliev, I.; Wegerich, K.; Kazbekov, J. The costs of benefit sharing: Historical and institutional analysis of shared water development in the ferghana valley, the Syr Darya Basin. Water 2015, 7, 2728-2752. [CrossRef]

22. Guillaume, J.; Kummu, M.; Eisner, S.; Varis, O. Transferable principles for managing the nexus: Lessons from historical global water modelling of Central Asia. Water 2015, 7, 4200-4231. [CrossRef]

23. Wegerich, K.; Van Rooijen, D.; Soliev, I.; Mukhamedova, N. Water security in the Syr Darya Basin. Water 2015, 7, 4657-4684. [CrossRef]

24. Jalilov, S.-M.; Varis, O.; Keskinen, M. Sharing Benefits in Transboundary Rivers: An Experimental Case Study of Central Asian Water-Energy-Agriculture Nexus. Water 2015, 7, 4778-4805. [CrossRef]

25. De Strasser, L.; Lipponen, A.; Howells, M.; Stec, S.; Bréthaut, C. A Methodology to Assess the Water Energy Food Ecosystems Nexus in Transboundary River Basins. Water 2016, 8, 59. [CrossRef]

26. Keskinen, M.; Someth, P.; Salmivaara, A.; Kummu, M. Water-energy-food nexus in a transboundary river basin: The case of Tonle Sap Lake, Mekong River Basin. Water 2015, 7, 5416-5436. [CrossRef]

27. Belinskij, A. Water-energy-food nexus within the framework of international water law. Water 2015, 7, 5396-5415. [CrossRef]

28. Matthews, N.; Motta, S. Chinese state-owned enterprise investment in mekong hydropower: Political and economic drivers and their implications across the water, energy, food nexus. Water 2015, 7, 6269-6284. [CrossRef]

29. Pittock, J.; Dumaresq, D.; Bassi, A. Modelling the hydropower-food nexus in large river basin. Water 2016, 8, 425. [CrossRef]

30. Endo, A.; Burnett, K.; Orencio, P.; Kumazawa, T.; Wada, C.; Ishii, A.; Tsurita, I.; Taniguchi, M. Methods of the water-energy-food nexus. Water 2015, 7, 5806-5830. [CrossRef]

31. Mekong River Commission. Integrated Water Resources Management-Based Basin Development Strategy 2016-2020 For the Lower Mekong Basin; Mekong River Commission: Vientiane, Laos, 2016.

32. Allouche, J.; Middleton, C.; Gyawali, D. Technical Veil, Hidden Politics: Interrogating the Power Linkages behind the Nexus. Water Altern. 2015, 8, 610-626.

33. Foran, T. Node and Regime: Interdisciplinary Analysis of Water-Energy-Food Nexus in the Mekong Region. Water Altern. 2015, 8, 655-674. 
34. UNECE. Task Force on the Water-Food-Energy-Ecosystems Nexus. Available online: http:/ /www.unece. org/env/water/task_force_nexus.html (accessed on 27 January 2016).

35. Pittock, J.; Hussey, K.; Dovers, S. Climate, Energy and Water: Managing Trade-Offs, Seizing Opportunities; Cambridge University Press: New York, NY, USA, 2015.

(c) 2016 by the authors; licensee MDPI, Basel, Switzerland. This article is an open access article distributed under the terms and conditions of the Creative Commons Attribution (CC-BY) license (http:/ / creativecommons.org/licenses/by/4.0/). 